Article

\title{
Anticancer Activity of the Choline Kinase Inhibitor PL48 Is Due to Selective Disruption of Choline Metabolism and Transport Systems in Cancer Cell Lines
}

\author{
Pablo García-Molina ${ }^{1,+}{ }^{+}$Alberto Sola-Leyva ${ }^{1,+}{ }^{+}$, Pilar M. Luque-Navarro ${ }^{2,3}$, Alejandro Laso ${ }^{1}$, \\ Pablo Ríos-Marco ${ }^{1}$, Antonio Ríos ${ }^{4}$, Daniela Lanari ${ }^{3}$, Archimede Torretta ${ }^{5}$, Emilio Parisini ${ }^{5,6}$ (D), \\ Luisa C. López-Cara ${ }^{2, * \mathbb{D}}$, Carmen Marco ${ }^{1, *}$ and María P. Carrasco-Jiménez ${ }^{1, * \mathbb{D}}$
}

check for updates

Citation: García-Molina, P.; Sola-Leyva, A.; Luque-Navarro, P.M.; Laso, A.; Ríos-Marco, P.; Ríos, A.;

Lanari, D.; Torretta, A.; Parisini, E.; López-Cara, L.C.; et al. Anticancer Activity of the Choline Kinase Inhibitor PL48 Is Due to Selective Disruption of Choline Metabolism and Transport Systems in Cancer Cell Lines. Pharmaceutics 2022, 14, 426. https://doi.org/10.3390/ pharmaceutics14020426

Academic Editor: Kishor M. Wasan

Received: 15 December 2021

Accepted: 14 February 2022

Published: 16 February 2022

Publisher's Note: MDPI stays neutral with regard to jurisdictional claims in published maps and institutional affiliations.

Copyright: (c) 2022 by the authors. Licensee MDPI, Basel, Switzerland. This article is an open access article distributed under the terms and conditions of the Creative Commons Attribution (CC BY) license (https:/ / creativecommons.org/licenses/by/ $4.0 /)$.
1 Department of Biochemistry and Molecular Biology I, University of Granada, 18071 Granada, Spain; pablo98@correo.ugr.es (P.G.-M.); albertosola@ugr.es (A.S.-L.); alejandrolaso@correo.ugr.es (A.L.); priosm@ugr.es (P.R.-M.)

2 Department of Pharmaceutical and Organic Chemistry, University of Granada, 18071 Granada, Spain; pilarluque@ugr.es

3 Department of Pharmaceutical Sciences, University of Perugia, 06123 Perugia, Italy; daniela.lanari@unipg.it

4 Department of Cell Biology, University of Granada, 18071 Granada, Spain; arios@ugr.es

5 Center for Nano Science and Technology @Polimi, Istituto Italiano di Tecnologia, Via Pascoli 70/3, 20133 Milano, Italy; archimede.torretta@iit.it (A.T.); emilio.parisini@osi.lv (E.P.)

6 Department of Biotechnology, Latvian Institute of Organic Synthesis, Aizkraukles 21, LV-1006 Riga, Latvia

* Correspondence: lcarlotalopez@ugr.es (L.C.L.-C.); cmarco@ugr.es (C.M.); mpazcj@ugr.es (M.P.C.-J.)

+ These authors contributed equally to this work.

\begin{abstract}
A large number of different types of cancer have been shown to be associated with an abnormal metabolism of phosphatidylcholine (PC), the main component of eukaryotic cell membranes. Indeed, the overexpression of choline kinase $\alpha 1$ (ChoK $\alpha 1)$, the enzyme that catalyses the bioconversion of choline to phosphocholine (PCho), has been found to associate with cell proliferation, oncogenic transformation and carcinogenesis. Hence, ChoK $\alpha 1$ has been described as a possible cancer therapeutic target. Moreover, the choline transporter CTL1 has been shown to be highly expressed in several tumour cell lines. In the present work, we evaluate the antiproliferative effect of PL48, a rationally designed inhibitor of ChoK $\alpha 1$, in MCF7 and HepG2 cell lines. In addition, we illustrate that the predominant mechanism of cellular choline uptake in these cells is mediated by the CTL1 choline transporter. A possible correlation between the inhibition of both choline uptake and ChoK $\alpha 1$ activity and cell proliferation in cancer cell lines is also highlighted. We conclude that the efficacy of this inhibitor on cell proliferation in both cell lines is closely correlated with its capability to block choline uptake and ChoK $\alpha 1$ activity, making both proteins potential targets in cancer therapy.
\end{abstract}

Keywords: cancer; lipid metabolism; choline kinase inhibitors; choline uptake

\section{Introduction}

Today, cancer continues to be one of the main causes of death worldwide, with an enormous social, economic and public health cost. The number of patients affected by cancer has been increasing in recent decades. According to annual data provided by the Global Cancer Observatory, in 2020, there were around 19.3 million cancer cases and approximately 10 million cancer deaths worldwide [1]. For this reason, the development of new effective and translational therapies, such as targeted therapies, is required. In these approaches, specific agents such as low molecular weight inhibitors or antibodies are designed to interact with specific enzymes or proteins that may be involved in important metabolic and/or oncogenic signalling pathways [2]. In this sense, the potential of targeting tumour energy metabolism for cancer treatment has been recently highlighted $[3,4]$. 
It has been widely reported that a large number of different types of cancer show abnormal metabolism of phosphatidylcholine (PC) [5-8], the most abundant phospholipid in the eukaryotic cell membrane. PC can be synthesised from choline, an organic cation that cannot freely cross the plasma membrane; so, it requires active transporters for its entry into the cell $[9,10]$. Upon entering the cell, choline is recruited along the Kennedy pathway, also called the CDP-choline pathway, leading to the synthesis of the phospholipid PC. An essential component of this pathway is choline kinase (ChoK), a cytosolic enzyme that catalyses the ATP-dependent phosphorylation of choline to phosphocholine (PCho) in the presence of magnesium.

In humans, the ChoK family is the result of the expression of two genes, chok- $\alpha$ and chok- $\beta$, which encode for three different isoforms of the enzyme: ChoK $\alpha 1$ (457 residues, $52 \mathrm{kDa}$ ), ChoK $\alpha 2$ (439 residues, $50 \mathrm{kDa}$ ) and ChoK $\beta$ (395 residues, $45 \mathrm{kDa}$ ). Each soluble active isoform is present as a homo- or heterodimer or as a tetramer. Hong et al. [11] provided the crystal structure of both the ChoK $\alpha 1$ and the ChoK $\beta$ isoform in complex with hemicholinium-3 (HC-3), a prototype for ChoK inhibitors [12]. In both structures (PDB code: 3G15 and 3LQ3), HC-3 is bound in the conserved hydrophobic groove at the C-terminal lobe of the enzyme; however, it was observed that actual inhibition occurs only when HC- 3 binds to the ChoK $\alpha 1$ isoform and not when it binds to the ChoK $\beta$ isoform.

The ChoK $\alpha 1$ isoform is considered an important anticarcinogenic and antiproliferative target due to the overexpression of the chok- $\alpha$ gene and to the increased activity of ChoK observed in cancer cell lines [12-15]. The higher levels of ChoK $\alpha 1$ activity found in tumours lead to an increase in PCho and PC levels, the latter being required for the synthesis of new cell membranes during cell proliferation [13]. This high enzymatic activity, as well as the overexpression of the chok- $\alpha$ gene, has been closely associated with alterations in oncogenic signalling pathways, such as PI3K/AKT or MAPK/AKT $[16,17]$. It is worth highlighting that hypoxia-response elements are present in the promoter sequence of chok$\alpha$, where hypoxia-inducible factors (HIF- $\alpha$ ) may bind. The binding of HIF- $1 \alpha$ enhances the overexpression of the chok- $\alpha$ gene in hypoxic environments such as those occurring in tumours [18].

Following the identification of ChoK $\alpha 1$ as a bona fide target in cancer therapy, during the past decade, several research groups have synthesized compounds that are capable of inhibiting this enzyme. The first of these, HC-3, features an $\mathrm{IC}_{50}$ value of $500 \mu \mathrm{M}$ for ChoK inhibition but blocks sodium-dependent choline transport and the synthesis of acetylcholine, thus showing numerous adverse effects. A symmetrical bis-pyridinium derivative, MN58b, and a symmetrical bis-quinolinium derivative RSM-932A (known as TCD-717) were subsequently synthesized, both of them showing reduced toxicity in human tumours [12].

Our group has long been involved in the design and synthesis of ChoK $\alpha 1$ inhibitors, which we have also tested for their antitumoral potency on several cancer cell lines. In the quest for more active and selective ChoK $\alpha 1$ inhibitors, the screening of different monoand bis- cationic compounds showed dissociation constants $(\mathrm{Kd})$ between $(82-35) \mu \mathrm{M}$ and $(0.62-0.11) \mu \mathrm{M}$, respectively. Similar results to $\mathrm{HC}-3\left(\mathrm{~K}_{\mathrm{d}}=0.180 \pm 0.05 \mu \mathrm{M}\right)$ were obtained for those biscationic molecules with longer linkers $(n=4)$ [19]. We recently studied two new symmetrical biscationic compounds-1,1'-((ethane-1,2-diylbis(oxy))bis(4,1-phenylene)), bis(methylene))-bispyridinium or -bisquinolinium bromide, EB-3D and EB-3P, respectively, which contain a pair of oxygen atoms in the spacer between the biscationic moieties. Both compounds inhibited ChoK $\alpha 1$ activity and HepG2 cell proliferation at low micromolar concentrations [20].

To date, our group has carried out studies with ChoK $\alpha 1$ inhibitors that have cationic heads derived from quinolinium, isoquinolinium or pyridinium. Our results indicate that, with these heads, changes in the spacer lead to more effective inhibition of the ChoK $\alpha 1$ enzyme while also causing antiproliferative activity $[19,21,22]$, albeit to variable extents in different cell lines. However, the main drawback of previously synthesised inhibitors resides in the lack of total convergence between the inhibition and antiproliferation values. 
Docking and SAR studies have provided evidence of the binding and activity of biscationic and symmetrical inhibitors, but biological tests have pointed out that other factors could be affecting the cell-growth outcome.

In previous reports, we have described that some ChoK $\alpha 1$ inhibitors are also capable of inhibiting choline transport, which could limit the intracellular availability of choline for PC biosynthesis $[20,23]$. Cellular choline uptake can be carried out by active transporters, low-affinity organic cation transporters (OCTs), intermediate-affinity choline transporterlike proteins (CTLs) and high-affinity choline transporters (CHTs). CHTs transport choline by a sodium-dependent mechanism, whereas OCTs and CTLs are sodium-independent transporters [24]. CHTs are present in cholinergic neurons and participate in acetylcholine synthesis. OCTs and CTLs are present in several tissues and supply choline mainly for the synthesis of PC and other phospholipids [10]. The expression and the function of choline transporters have not been well identified in cancer, although overexpression of CTL1 has been found in malignant cells and tumours of the liver, lung, colon, breast, prostate and ovaries $[12,25,26]$. In addition, Watanabe et al. [27] showed that the choline transporter CTL1 is highly expressed in tumour cells and that the inhibition of CTL1 function induces apoptotic cell death, making CTL1 a potential target in cancer therapy.

Our goal is to obtain more potent and selective ChoK $\alpha 1$ inhibitors that also feature increased antiproliferative activity in cell lines of different origins. For this reason, we focus on the synthesis of symmetrical bioisosteric molecules with different electron donor or acceptor groups in the linker, with the purpose of (1) increasing the binding interaction with the enzyme and (2) improving key parameters such as the solubility of the inhibitors. In this study, a new ChoK $\alpha 1$ inhibitor called PL48 (Figure 1) is presented. Owing to the presence of sulphur atoms in the linker, PL48 shows a higher lipophilicity than its predecessor EB-3P ( $\log p=7.07$ vs. 6.03, both values calculated using http://www.swissadme.ch/ (last access the 29 December 2021) as an average of five prediction methods). Moreover, sulphur free-electron pairs allow the establishment of new interactions within the cholinebinding pocket of ChoK $\alpha 1$, improving its affinity for the enzyme. Preliminary docking studies predicted the dithioethane linker to sit in a more polar interloop region (L1-L9) with which it can interact. In comparison, the crystal structure of the diphenoxyethane homologous crystal structure (PDB code: 5FTG) showed the allocation of the linker in a more hydrophobic cage, mostly interacting through the phenyl group via $\pi-\pi$ stacking with Tyr354 and Phe435. In addition, the sulphur-containing linker, even when most exposed, leads to less solvation than do the most hydrophilic oxygen and thus to better interactions with the enzyme.

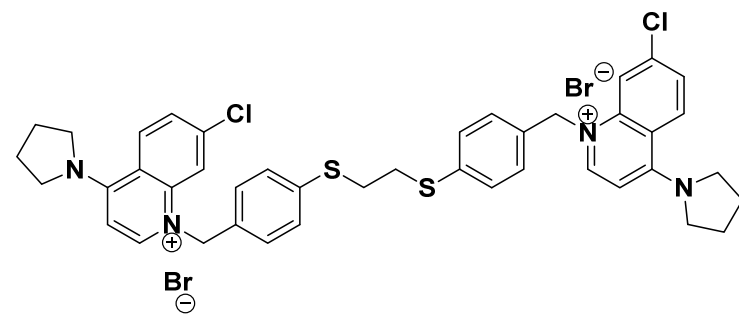

Figure 1. Chemical structure of synthetic ChoK $\alpha 1$ inhibitor PL48.

No PAINS (Pan Assay Interference Structures) were detected for the new inhibitor, ex-cluding the possibility of side effects due to unspecific activity of the chemical structure.

In the present study, we examined the effect of PL48 on ChoK $\alpha 1$ expression and activity, as well as on the activity of the main choline transporters involved in the choline uptake in HepG2 and MCF7 cancer cell lines. Our objective was to determine the correlation between ChoK $\alpha 1$ activity and choline uptake on cell proliferation. 


\section{Materials and Methods}

\subsection{Materials}

Foetal Bovine Serum (FBS), Eagle's Minimum Essential Medium (MEM) and RPMI1640 (Roswell Park Memorial Institute 1640) were obtained from Biowest (Nuaillé, France). Thin Layer Chromatography (TLC) plates and protease inhibitor cocktail were from SigmaAldrich (Madrid, Spain). [Methyl- ${ }^{14} \mathrm{C}$ ]choline was from Perkin Elmer (Madrid, Spain). Mini-PROTEAN ${ }^{\circledR}$ TGX Stain-Free Protein Gels, Trans-Blot Turbo Mini PVDF and Clarity Western ECL substrate were from Bio-Rad Laboratories, Inc. (Madrid, Spain). Monoclonal anti-human primary antibodies ChoK $\alpha$ (sc-23382) and polyclonal $\beta$-actin were from Santa Cruz Biotechnology, Inc. (Heidelberg, Germany). Rabbit polyclonal SLC44A1/CTL1 antibody (ab110767) was from Abcam (Cambridge, MA, USA). Horseradish peroxidase (HRP)-linked secondary IgGs were from Cell Signaling Technology (Danvers, MA, USA). The pET-28a vector and Escherichia coli BL21 (DE3) Star cells were from Invitrogen (Carlsbad, CA, USA), N-terminal 6x His-tag was purchased from Genescript (Piscataway, NJ, USA), Ni-NTA agarose beads were from Qiagen (Venlo, The Netherlands), and HiPrep 26/60 Sephacryl 100 HR column was from GE Healthcare (Little Chalfont, Buckinghamshire, UK). All other reagents were of analytical grade.

\subsection{Cell Culture}

The breast cancer cell line MCF7 (Michigan Cancer Foundation-7) and the liver cancer cell line HepG2 (Hepatoblastoma G2) were provided by the European Collection of Animal Cell Cultures (Salisbury, UK). MEM and RPMI-1640 were used to culture HepG2 and MCF7, respectively, and were both supplemented with $10 \%(v / v)$ heat-inactivated FBS, penicillin $(100 \mathrm{IU} / \mathrm{mL})$ and streptomycin $(100 \mu \mathrm{g} / \mathrm{mL})$. L-glutamine at a concentration of $2 \mathrm{mM}$ was also exogenously added. Cells were incubated at $37{ }^{\circ} \mathrm{C}$ in a humidified atmosphere with $5 \% \mathrm{CO}_{2}$. When the cells reached high confluence, subculturing was carried out in a fresh medium.

\subsection{Choline Uptake Assays}

To study choline uptake, 300,000 MCF7 or HepG2 cells/well were seeded in 12-well plates. After $24 \mathrm{~h}$, the culture medium was carefully aspirated, and the wells were washed twice with sodium-free buffer (SFB). This buffer contained $280 \mathrm{mM}$ D-mannitol, $4.8 \mathrm{mM}$ $\mathrm{KCl}, 1.2 \mathrm{mM} \mathrm{CaCl}_{2}, 1.2 \mathrm{mM} \mathrm{KH}_{2} \mathrm{PO}_{4}, 5.6 \mathrm{mM}_{\text {glucose, }} 1.2 \mathrm{mM} \mathrm{MgSO}_{4}$ and $25 \mathrm{mM} \mathrm{HEPES}$ ( $\mathrm{pH}$ 7.4). Then, $250 \mu \mathrm{L}$ of SFB containing isotopically labelled choline was added to each well $(36 \mu \mathrm{M}, 55 \mathrm{Ci} / \mathrm{mol})$.

For kinetic studies, when it was necessary, unlabelled choline was added in different amounts to obtain the required concentrations. The range of choline concentrations used for the assays was 1 to $1000 \mu \mathrm{M}$. The plates were incubated for $10 \mathrm{~min}$ at $37^{\circ} \mathrm{C}$ and then placed on ice to block choline uptake by cells. After this, the medium was removed, and the wells were washed twice with concentrated unlabelled choline $(580 \mu \mathrm{M})$. Subsequently, the cell monolayer was solubilised in $\mathrm{NaOH} 0.1 \mathrm{~N}$, and aliquots were taken to measure radioactivity in a Beckman liquid scintillation counter (Model LS-6000-TA, Beckman, Madrid, Spain). From the analysis of the results, Michaelis-Menten ([choline] vs. v) and Eadie-Hofstee graphs ( $\mathrm{v} /[$ choline] vs. $\mathrm{v})$ were obtained to determine the maximum velocity $\left(\mathrm{V}_{\max }\right)$ and the Michaelis constant $\left(\mathrm{K}_{\mathrm{M}}\right)$ for the choline transport kinetics.

In parallel, to better understand the choline transporters involved in choline uptake, we measured the incorporation of choline into cells in the presence of increasing concentrations of well-known choline transporter inhibitors, HC-3 and tetraethylammonium (TEA), or in the presence of PL48 synthesised as a ChoK $\alpha 1$ inhibitor. HC-3 and TEA are validated inhibitors of the CHT/CTL and OCT proteins, respectively. Samples were processed as described above. 


\subsection{Cloning, Protein Expression and Purification of ChoK $\alpha 1$}

A truncated form of ChoK $\alpha 1(\Delta 75-457)$ cloned into a pET-28a vector and featuring an N-terminal 6x His-tag was used to transform E. coli BL21 (DE3) Star cells. The transformed cells were cultured in Luria-Bertani (LB) medium at $37^{\circ} \mathrm{C}$ until $\mathrm{OD}_{600}=0.6$. After induction with $1 \mathrm{mM}$ isopropyl $\beta$-D-1-thiogalactopyranoside (IPTG), the bacterial cell culture was grown overnight at $20^{\circ} \mathrm{C}$ and $180 \mathrm{rpm}$. The cellular pellet was then separated from the exhausted medium by centrifugation at 10,000 rpm, resuspended in $50 \mathrm{mM}$ Tris$\mathrm{HCl}$ pH 7.5, $500 \mathrm{mM} \mathrm{NaCl}, 0.2 \mathrm{mM}$ phenylmethylsulphonyl fluoride (PMSF), DNase and $0.5 \mathrm{mM} \beta$-mercaptoethanol, and sonicated. The soluble fraction containing the enzyme was separated from the insoluble fraction by centrifugation at $15,000 \mathrm{rpm}$ and $4{ }^{\circ} \mathrm{C}$. A two-step purification protocol was employed to isolate the target enzyme. The first step was performed using Ni-NTA affinity chromatography. The cell lysate was first incubated for $45 \mathrm{~min}$ with Ni-NTA agarose beads. Then, the column was extensively washed with 40 column volumes (CV) of $50 \mathrm{mM}$ Tris- $\mathrm{HCl} \mathrm{pH}$ 7.5, $300 \mathrm{mM} \mathrm{NaCl}, 10 \mathrm{mM}$ imidazole and $1 \mathrm{CV}$ of $50 \mathrm{mM}$ Tris- $\mathrm{HCl} \mathrm{pH} \mathrm{7.5,300} \mathrm{mM} \mathrm{NaCl}$ and $40 \mathrm{mM}$ imidazole. Finally, the His-tagged enzyme was eluted from the column with $50 \mathrm{mM}$ Tris- $\mathrm{HCl}$ pH 7.5, $300 \mathrm{mM}$ $\mathrm{NaCl}$ and $400 \mathrm{mM}$ imidazole. The second purification step was performed by size-exclusion chromatography using a HiPrep 26/60 Sephacryl 100 HR column (GE Healthcare, Little Chalfont, Buckinghamshire, UK), which was previously equilibrated with $20 \mathrm{mM}$ Tris/HCl $\mathrm{pH} 7.5$ and $150 \mathrm{mM} \mathrm{NaCl}$ running buffer. After the two purification steps, a highly pure sample was obtained, and the final enzyme yield was $1.25 \mathrm{mg}$ of recombinant protein per litre of bacterial culture.

\subsection{Preparation of Cell Lysate Containing Soluble ChoKd}

MCF7 or HepG2 cells were seeded at a concentration of $1 \times 10^{6}$ cells/well in 6-well plates. After seeding, the medium was removed and replaced with a fresh medium containing $1 \mu \mathrm{M}$ PL48 or none as a control. After $48 \mathrm{~h}$, cell lysate was obtained as described by Jiménez-López et al. [28] with minor modifications. Briefly, cells were scraped into PBS and centrifuged at $1500 \mathrm{rpm}$ for $5 \mathrm{~min}$. The cell pellet was resuspended in $100 \mathrm{mM}$ Tris- $\mathrm{HCl} \mathrm{pH} 8.5$ and sonicated for $3 \mathrm{~s}$ with a microprobe in an ice bath, and the lysate was immediately frozen in liquid nitrogen and stored at $-80^{\circ} \mathrm{C}$ until use.

\subsection{Determination of ChoK $\alpha$ Activity}

To study the effect of PL48 on ChoK $\alpha$, an in vitro enzymatic assay was performed with the purified enzyme or the cell lysate containing the enzyme, as previously reported by Schiaffino-Ortega et al. [21] and by Schiaffino-Ortega et al. [29], respectively. Briefly, the incorporation of ${ }^{14} \mathrm{C}$ from [methyl- $-{ }^{14} \mathrm{C}$ ]choline into PCho in either the absence (control) or presence of different PL48 inhibitor concentrations was used to determine the ChoK activity. For the purified enzyme assay, the reaction mixture included $20 \mathrm{ng}$ of purified ChoK $\alpha 1$, $10 \mathrm{mM}$ ATP, $10 \mathrm{mM} \mathrm{MgCl} 2,100 \mathrm{mM}$ Tris- $\mathrm{HCl} \mathrm{pH} 8.5$ and increasing concentrations of PL48. Samples were preincubated at $37^{\circ} \mathrm{C}$ for $5 \mathrm{~min}$, and then a pulse of [methyl $-{ }^{14} \mathrm{C}$ ]choline chloride $(1 \mathrm{mM}, 4500 \mathrm{dpm} / \mathrm{nmol})$ was added, and the reaction proceeded for $10 \mathrm{~min}$ at $37^{\circ} \mathrm{C}$. When determining ChoK $\alpha$ activity in cell lysate, the procedure was similar, but $50 \mu \mathrm{g}$ of protein was added, and after preincubation at $37^{\circ} \mathrm{C}$ for $5 \mathrm{~min}$, the reaction was initiated with $1 \mathrm{mM}$ [methyl $-{ }^{14} \mathrm{C}$ ]choline $(4500 \mathrm{dpm} / \mathrm{nmol})$ and was incubated at $37^{\circ} \mathrm{C}$ for $20 \mathrm{~min}$.

The assay was stopped by immersing the reaction tubes in boiling water for $3 \mathrm{~min}$. Aliquots of the supernatant were applied to the origin of silica gel plates in the presence of PCho $(0.1 \mathrm{mg})$ and choline $(0.1 \mathrm{mg})$ as carriers. The TLC plates were developed in methanol $/ 0.6 \% \mathrm{NaCl} / 28 \% \mathrm{NH}_{4} \mathrm{OH}$ in water $(50: 50: 5, v / v / v)$ as solvent. PCho was visualised under exposure to iodine vapour, and the corresponding spot was scraped and transferred to scintillation vials for measurement of radioactivity by a Beckman 6000-TA (Madrid, Spain) liquid scintillation counter. The 50\% inhibitory concentrations ( $\mathrm{IC}_{50}$ values) were determined from the $\%$ enzyme activity at different concentrations of synthetic 
inhibitors relative to the control by using a sigmoidal dose-response curve (ED50plus v1.0 software).

\subsection{Evaluation of the Antiproliferative Effect of PL48 in HepG2 and MCF7 Cell Lines}

HepG2 and MCF7 were seeded onto 96-well plates (10 000 cells/well) and maintained in medium for $24 \mathrm{~h}$. Then, the culture medium was replaced with fresh medium, and the cells were incubated for 24 or $48 \mathrm{~h}$ in the absence or presence of different amounts of PL48. The antiproliferative effect of PL48 was evaluated by crystal violet staining assay using a cell-number-based standard curve, as previously reported [30]. The absorbance of crystal violet in each well was measured at a wavelength of $590 \mathrm{~nm}$ directly in plates using a Synergy ${ }^{\text {TM }}$ HTX Multi-Mode microplate reader through Gen $5{ }^{\circledR}$ software (BioTek, Oxford, UK).

\subsection{Immunoblotting Assay}

MCF7 or HepG2 cells growing in the log phase were incubated for $48 \mathrm{~h}$ with medium in the absence or presence of $1 \mu \mathrm{M}$ PL48. Then, the cell monolayers were washed with cold PBS and subsequently scraped in PBS, followed by centrifugation $\left(2500 \mathrm{rpm} / 5 \mathrm{~min} / 4^{\circ} \mathrm{C}\right.$ ). The pellet was resuspended in lysis buffer, which contained $50 \mathrm{mM}$ Tris- $\mathrm{HCl}, \mathrm{pH}=7.4$, $150 \mathrm{mM} \mathrm{NaCl}, 1 \%$ Triton X-100, protease inhibitor cocktail, $1 \mathrm{mM}$ sodium orthovanadate and $57.4 \mathrm{mM}$ PMSF. The tubes were kept on ice for $30 \mathrm{~min}$ accompanied by vortexing every $5 \mathrm{~min}$. Then, a second centrifugation was performed $\left(13000 \mathrm{rpm} / 15 \mathrm{~min} / 4^{\circ} \mathrm{C}\right)$, and the supernatants were collected and stored at $-80^{\circ} \mathrm{C}$. Equal protein amounts from lysates were separated by SDS-PAGE and transferred to PVDF membranes. Prestained protein molecular weight markers were used. Membranes were blocked in 5\% non-fat dried milk in TBS and $0.05 \%$ Tween-20 in TBS for $1 \mathrm{~h}$ and incubated with CTL1 (1:500) or ChoK (1:200) primary antibodies. The corresponding horseradish peroxidase (HRP)-conjugated IgG $(1: 5000)$ was used as a secondary antibody and incubated for $1 \mathrm{~h}$. Immunoreactive proteins were detected using ECL substrate, and the membranes were imaged using the Molecular Imager ChemiDocTM MP System (Bio-Rad Laboratories, Inc., Madrid, Spain).

\subsection{Metabolic Labelling Assays}

MCF7 and HepG2 (300,000 cells/well) were incubated in both the presence and absence of $1 \mu \mathrm{M}$ PL48 for $48 \mathrm{~h}$. [Methyl- ${ }^{14} \mathrm{C}$ ]choline $(60 \mu \mathrm{M}, 33 \mathrm{Ci} / \mathrm{mol})$ was added in the last $4 \mathrm{~h}$ of the incubation period. Lipid biosynthetic activity was estimated according to the level of incorporation of radiolabelled choline into corresponding metabolites of PC synthesis. Water-soluble and lipid fractions were extracted from the cells following the procedure of Bligh and Dyer [31]. PC and sphingomyelin (SM) were separated from the chloroformic phase on silica-gel $60 \mathrm{G}$ TLC plates using a mixture of chloroform/methanol/acetic acid/water (60:30:8:5, $v / v)$ as a solvent. Choline and PCho were separated from the watermethanol phase by TLC using a solvent of methanol $/ 0.6 \% \mathrm{NaCl} / \mathrm{NH}_{4}(10: 10: 1, v / v)$. The spots were made visible by exposure to iodine vapour and radiometrically measured by liquid scintillation using a Beckman 6000-TA counter (Madrid, Spain).

\subsection{Other Analyses}

Cell protein content was determined using the method of Bradford [32] with BSA as the standard.

\subsection{Statistical Analysis}

The results are expressed as means \pm SEM (standard error of the mean). A oneway ANOVA was conducted with post hoc comparisons by Scheffé's test (SPSS 13.0) using GraphPad Software Inc. (San Diego, CA, USA). $p$-value $<0.05$ is considered statistically significant. Asterisks indicate the following $p$-value ranges: ${ }^{*} p<0.05,{ }^{* *} p<0.001$, *** $p<0.0001$. 


\section{Results and Discussion}

\subsection{Functional Characteristics of Choline Uptake in MCF7 and HepG2 Cells}

Choline is an organic cation constituent of choline-containing lipids such as PC and SM, lipoproteins, bile lipids and pulmonary surfactant [33]. Cell membranes are not permeable to choline $[9,34]$; thus, in this work, we characterised the kinetics of choline uptake by MCF7 and HepG2 cancer cell lines. For this purpose, cells were incubated for $10 \mathrm{~min}$ with [methyl- ${ }^{14} \mathrm{C}$ ]choline with substrate concentrations ranging between 1 and $1000 \mu \mathrm{M}$ in the absence of sodium. In both cell lines, plots of the uptake kinetics exhibited a typical hyperbolic appearance (Figure 2A). The Eadie-Hofstee plots showed a concave appearance with two straight lines with different slopes, indicating clearly that, in both cell types, two different choline transport systems were involved (Figure 2B,C, left graphs). The kinetic constants determined using the initial rates obtained with a low concentration of substrate $(1-36 \mu \mathrm{M})$ (middle plots) were: $\mathrm{K}_{\mathrm{M}}=5.38 \mu \mathrm{M}$ and $\mathrm{V}_{\max }=0.85 \mathrm{nmol} / \mathrm{min} / \mathrm{mg}$ protein for HepG2 cells. Similar values were obtained in MCF7 cells $\left(\mathrm{K}_{\mathrm{M}}=5.67 \mu \mathrm{M}\right.$ and $\mathrm{V}_{\max }=0.37 \mathrm{nmol} / \mathrm{min} / \mathrm{mg}$ protein $)$. When using higher choline concentrations $(60-1000 \mu \mathrm{M})$ (right graphs), the kinetic constants for HepG2 cells $\left(\mathrm{K}_{\mathrm{M}}=183.57 \mu \mathrm{M}\right.$ and $\mathrm{V}_{\max }=2.75 \mathrm{nmol} / \mathrm{min} / \mathrm{mg}$ protein $)$ and $\mathrm{MCF}$ cells $\left(\mathrm{K}_{\mathrm{M}}=137.16\right.$ and $\mathrm{V}_{\max }=2.48 \mathrm{nmol} / \mathrm{min} / \mathrm{mg}$ protein) were also similar. These results reveal that in both HepG2 and MCF7 cancer cell lines, $K_{M}$ values for transporter-mediated uptake were in the intermediate-affinity and low-affinity ranges [10]. Previously reported data in several cell lines suggested that two different transport systems with different affinities for choline cooperate to enable choline entry into the cell [35]. In several tissues, the involvement of low-affinity and intermediate-affinity choline transporters has also been described $[35,36]$.
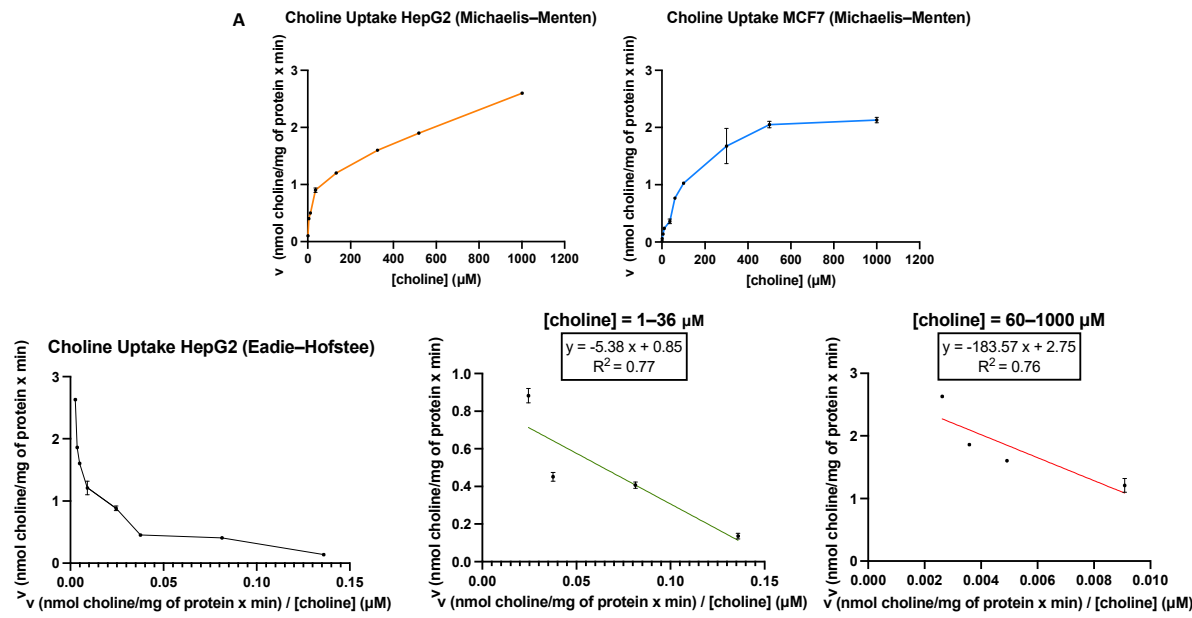

c
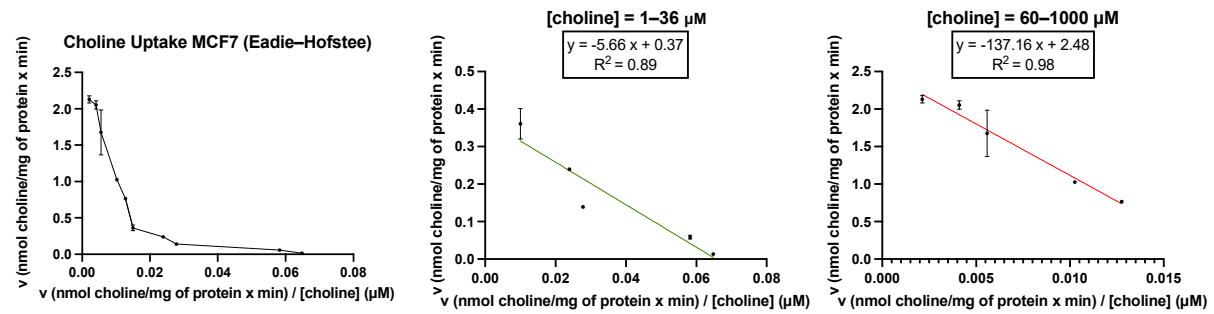

Figure 2. (A) [Methyl- ${ }^{14} \mathrm{C}$ ]choline uptake by HepG2 and MCF7 cells was assayed for 10 min over a concentration range from 1 to $1000 \mu \mathrm{M}$ choline. Representative Eadie-Hofstee plots for [methyl${ }^{14} \mathrm{C}$ choline uptake in HepG2 (B) and MCF7 (C). The kinetic constants $\left(\mathrm{K}_{\mathrm{M}}\right.$ and $\left.\mathrm{V}_{\max }\right)$ for transporter proteins were determined using equations from the Eadie-Hofstee plots obtained with low $(1-36 \mu \mathrm{M})$ and high $(60-1000 \mu \mathrm{M})$ choline substrate concentrations. Data are representative of two independent experiments performed in triplicate. 


\subsection{Effect of HC-3 and TEA on Choline Uptake in MCF7 and HepG2 Cells}

HC-3 and TEA are validated inhibitors of the CHT/CTL and OCT proteins, respectively. Therefore, to further characterise the choline transport systems, we carried out competition assays with these inhibitors in both cell lines. Measures of inhibition using HC-3, a well-known competitive inhibitor of high-affinity choline transport at low concentrations $(<1 \mu \mathrm{M})$, indicated that choline uptake was not inhibited. However, treatments with higher concentrations of HC-3 to target other HC-3-sensitive transporters, such as CTL1-mediated transport, caused the blockage of choline uptake compared with control cells. Inhibition using HC-3 concentrations ranging from $2 \mu \mathrm{M}$ to $150 \mu \mathrm{M}$ resulted in $\mathrm{IC}_{50}$ values of $29.42 \pm 0.97 \mu \mathrm{M}$ for HepG2 cells and $39.06 \pm 6.95 \mu \mathrm{M}$ for MCF7 cells (Figure 3A and $3 \mathrm{~B}$, respectively). These results exclude the participation of the sodium-dependent CHT1 transporter, which is expressed mainly in neuronal tissue, very sensitive to HC-3, and a limiting step in acetylcholine biosynthesis in cholinergic neurons. In the cells used in our study, experimental data indicate that the transporter involved could be CTL1, which has an intermediate affinity for choline, with a $\mathrm{K}_{\mathrm{M}}$ in the low micromolar range. Similar to the high-affinity choline transporter CHT1, CTL1 is selectively inhibited by HC-3 but with a lower level of sensitivity $(10-100 \mu \mathrm{M})[9]$.
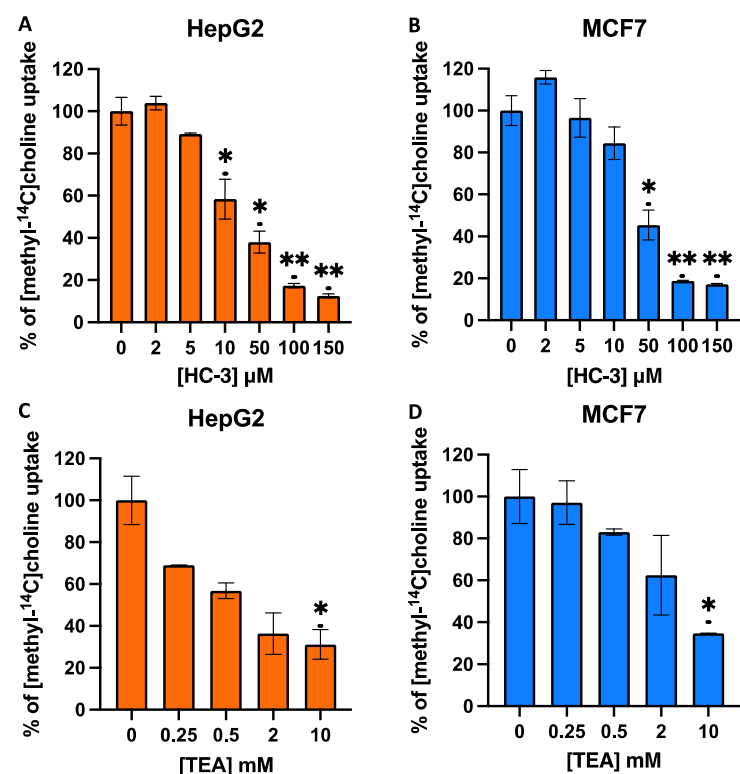

Figure 3. Effects of hemicholinium-3 (HC-3) (A,B) or tetraethylammonium (TEA) (C,D) on choline uptake in HepG2 and MCF7 cell lines. Choline uptake was assayed in cells treated for 10 min with increasing concentrations of inhibitors dissolved in sodium-free buffer (SFB). Data represent the mean \pm SEM of two independent experiments conducted in triplicate. Results are normalised to their respective controls. ${ }^{*} p<0.05,{ }^{* *} p<0.001$.

The inhibitor of the OCT family of transporters, TEA, showed significant effects on choline uptake only at very high concentrations. As shown in Figure 3, TEA only caused weak inhibition, showing $\mathrm{IC}_{50}$ values at a concentration greater than $1 \mathrm{mM}$; hence, OCTmediated choline uptake in HepG2 and MCF7 must be negligible (Figure 3C,D), and it is probable that OCTs do not significantly contribute to choline uptake in these cell types. These data agree with results previously reported by Sinclair et al. [36] in the liver and those reported by Morse et al. [37], who described the low expression of OCT transporters in MCF7 cells. In summary, this study suggests the functional role of CTL1 as a choline transporter in MCF7 and HepG2 cells. Thus, we focused our study on the CTL1 choline transporter, which is expressed in different organisms and cell types, apparently not for the biosynthesis of acetylcholine but for the production of the most abundant metabolite of choline, the membrane lipid PC $[38,39]$. 


\subsection{PL48 Inhibits Cell Growth in MCF7 and HepG2 Cells}

In tumour cells and in tumour progression, PC biosynthesis is greater than in normal tissue. Furthermore, the overexpression of the ChoK $\alpha 1$ isoform and CTL1 has been found in several malignant cells and tumours $[12,25,26]$. This suggests that the metabolism of choline and related compounds is a metabolic hallmark of tumour onset and progression. In light of such data, we previously synthesised ChoK $\alpha 1$ inhibitors that showed antiproliferative activity in different cell lines [23,40]. One series of such inhibitors comprised symmetrical biscationic compounds, bis-pyridinium and bis-quinolinium derivatives with 1,2-diphenoxyethane as a spacer between the bi-pyridine or bi-quinoline rings. Among this last series of compounds, it is worth highlighting compounds 10a (also called EB-3D) and 101 (called EB-3P), which inhibit ChoK $\alpha 1$ with similar $\mathrm{IC}_{50}$ values of around $1 \mu \mathrm{M}$ and show $\mathrm{GI}_{50}$ values in the HepG2 cell line of 14.55 and $4.81 \mu \mathrm{M}$, respectively [20].

PL48 is a bioisostere of the ChoK $\alpha 1$ inhibitor EB-3P. As can be seen from its structure (Figure 1), PL48 contains a pair of sulphur atoms in the spacer of the linker between the biscationic moieties, while EB-3P has two O-atoms [20]. The presence of sulphur atoms between the quinoline cationic heads increases its lipophilicity. We evaluated the dose-dependent antiproliferative activity of PL48 against the HepG2 and MCF7 cell lines, identifying $\mathrm{GI}_{50}$ values of $0.972 \pm 0.240 \mu \mathrm{M}$ for HepG2 and $1.34 \pm 0.480 \mu \mathrm{M}$ for MCF7 after $48 \mathrm{~h}$ of treatment (Figure $4 \mathrm{~A}$ and $4 \mathrm{~B}$, respectively). This antiproliferative action could not be attributed to lysis as measured by LDH release into the medium (data not shown). Our results indicate that in these cell lines, (i) PL48 had higher antiproliferative activity than its bisquinolinium predecessor EB-3P, which is a ChoK $\alpha 1$ inhibitor previously studied by our group [20], and (ii) both cell lines show the same sensitivity to PL48.

A

HepG2

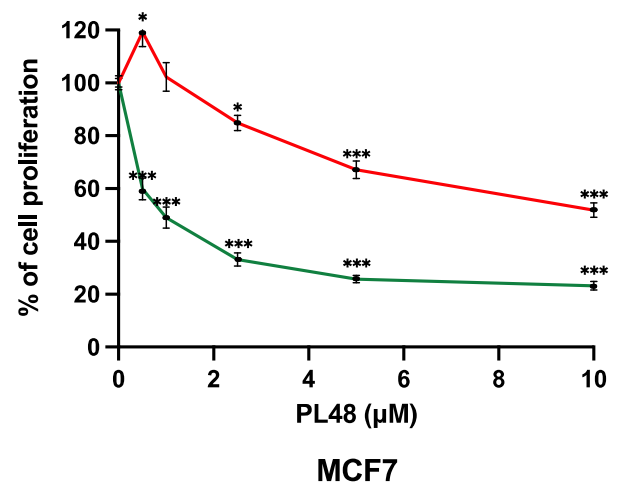

$-24 \mathrm{~h}$

$-48 \mathrm{~h}$

B



Figure 4. Effects of PL48 inhibitor on (A) HepG2 and (B) MCF7 cell proliferation. Cells growing in the log phase were incubated with MEM (HepG2) or RPMI-1640 (MCF7) in the presence or absence of PL48 at concentrations of up to $10 \mu \mathrm{M}$ for 24 or $48 \mathrm{~h}$. Cell number was determined by crystal violet staining and expressed as a percentage of the control cells. These experiments were performed twice in triplicate. ${ }^{*} p<0.05,{ }^{* * *} p<0.0001$. 


\subsection{Inhibition of ChoK $\alpha 1$ by PL48}

In order to assess the efficacy of PL48 in inhibiting the target protein for which it has been designed, the effect of PL48 on human recombinant ChoK $\alpha 1$ was assayed by determining the rate of incorporation of ${ }^{14} \mathrm{C}$ from $\left[\right.$ methyl- $\left.{ }^{14} \mathrm{C}\right]$ choline into PCho in the absence or presence of different PL48 concentrations, as previously described [21,40]. As shown in Figure 5, PL48 inhibits ChoK $\alpha 1$ activity with an $\mathrm{IC}_{50}$ value of $0.658 \pm 0.067 \mu \mathrm{M}$, below that of previously studied symmetrical biscationic compounds [21].

\section{ChoK $\alpha$ activity}

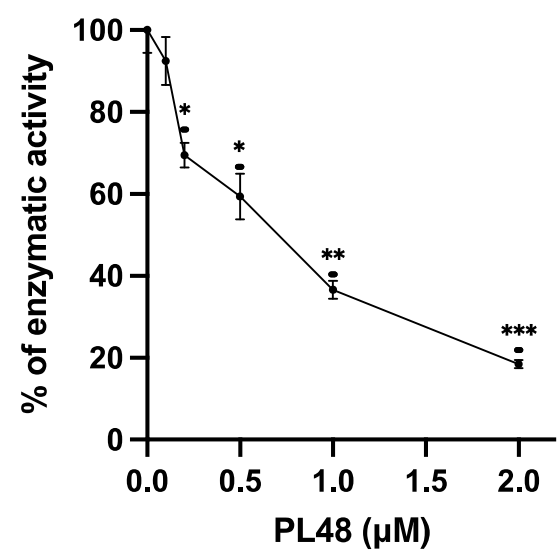

Figure 5. Effects of PL48 on choline kinase (ChoK) $\alpha 1$ activity. ChoK $\alpha 1$ activity was determined by the incorporation rate of ${ }^{14} \mathrm{C}$ from [methyl- ${ }^{14} \mathrm{C}$ ]choline into phosphocholine (PCho) in the absence or presence of different PL48 concentrations. The results are expressed as the percentage of enzymatic activity compared with the control. ${ }^{*} p<0.05,{ }^{* *} p<0.001,{ }^{* * *} p<0.0001$.

In Figure 6, the improved potency of the inhibitor that contains the dithioethane linker is shown. Sulphur bioisosteric substitution confers a more lipophilic character to the molecule.

\section{BIOISOSTERIC CHANGE IN THE LINKER}

a.

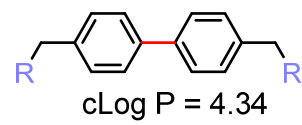

b.

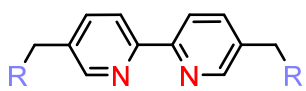

CLog $\mathrm{P}=2.47$

c.
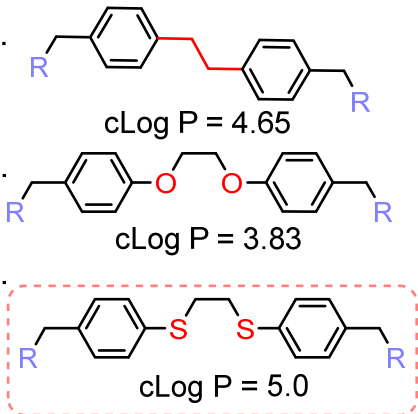

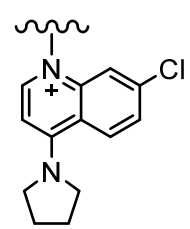

a. $\mathrm{IC}_{50}=19.8 \mu \mathrm{M}$

b. $I C_{50}=17.7 \mu \mathrm{M}$

c. $\mathrm{IC}_{50}=1 \mu \mathrm{M}$

d. $I C_{50}=0.92 \mu \mathrm{M}$

e. $I_{50}=0.66 \mu \mathrm{M}$

Figure 6. Effect of the linker bioisosteric change in the inhibitory activity towards the ChoK $\alpha 1$. The $\mathrm{IC}_{50}$ values of compounds (a-d) are taken from [21,41,42], (e) corresponds to PL48. 


\subsection{Effect of PL48 on Choline Uptake in HepG2 and MCF7 Cell Lines}

As mentioned above, we have described that some $\mathrm{ChoK} \alpha 1$ inhibitors are also capable of inhibiting choline transport $[20,23]$. According to our results, in cells treated for $10 \mathrm{~min}$ with the inhibitor PL48, choline uptake was strongly inhibited, featuring $\mathrm{IC}_{50}$ values of $0.09 \pm 0.03 \mu \mathrm{M}$ for HepG2 and $0.26 \pm 0.01 \mu \mathrm{M}$ for MCF7 (Figure 7).
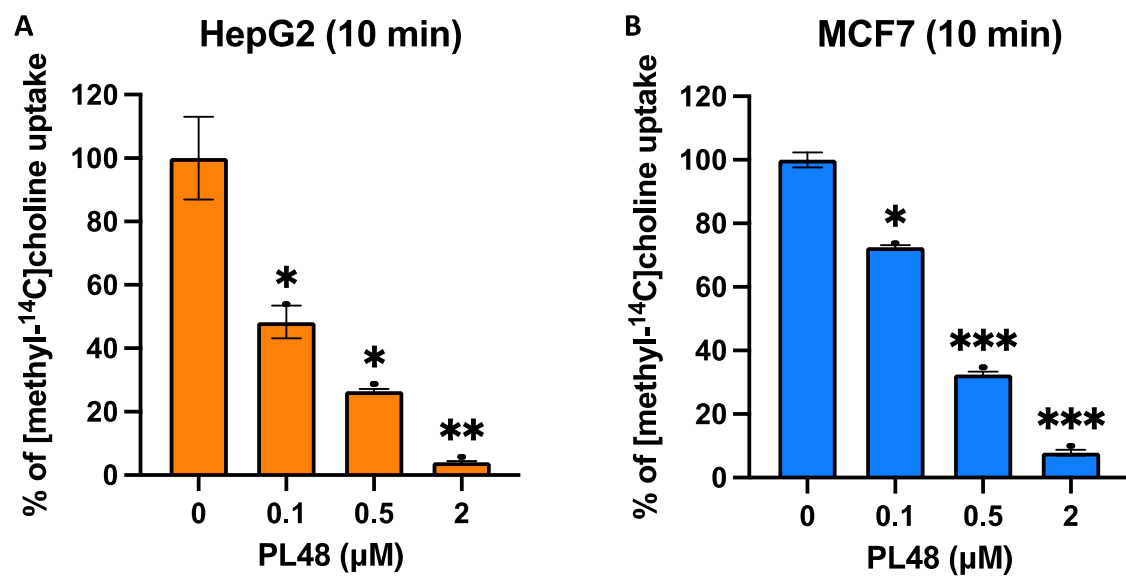

Figure 7. Effects of PL48 on choline uptake in HepG2 (A) and MCF7 (B) cancer cell lines. Choline uptake was assayed in cells treated for $10 \mathrm{~min}$ with increasing concentrations of inhibitor. Data represent the mean \pm SEM of two independent experiments conducted in triplicate. Results are normalised to their respective controls. ${ }^{*} p<0.05,{ }^{* *} p<0.001,{ }^{* * *} p<0.0001$.

\subsection{Effect of PL48 Treatment for $48 \mathrm{~h}$ on ChoKd and CTL1 Expression Levels in MCF7 and HepG2 Cells}

Previous studies have reported the overexpression of ChoK $\alpha$ in several cancer-derived cell lines [43,44]. ChoK inhibition or ChoK $\alpha$ downregulation leads to a decrease in PCho levels in the malignant cells, coupled with a decrease in cell proliferation $[5,15,45-47]$, demonstrating a causal link between $\mathrm{ChoK} \alpha$ elevation and carcinogenesis and tumour progression.

In this context, our research group showed that EB-3D and EB-3P act as ChoK $\alpha 1$ inhibitors and decrease the expression levels of this enzyme [20]. Some works, however, have shown that the inhibition of the enzyme in MCF7 cells produces an increase in the expression of both CTL1 and ChoK, raising PCho levels, which is used as a noninvasive response biomarker after cancer treatment [48]. These results are controversial, since elevated PCho levels are generally associated with cancer progression [5,15,45-47].

In the present study, we analyse the expression levels of ChoK $\alpha$ and CTL1 in both HepG2 and MFC7 cells after treatment with PL48 for $48 \mathrm{~h}$. To assess the effect of PL48 on the levels of these two proteins in both cell types, we treated cells with PL48, and cell lysates were prepared as described in the Materials and Methods section. The images of ChoK $\alpha$ expression levels from HepG2 cells and MCF7 are represented in Figure 8. As shown in the figure, in control cells, ChoK $\alpha$ levels are higher in MCF7 than in HepG2. The literature includes works that support these results, such as those presented by See Too et al. [49], who detected $\alpha 1$ and $\alpha 2$ isoforms of ChoK in several cancer cell lines. These authors observed that MCF7 cells showed higher expression of total ChoK $\alpha$ compared with HepG2 cells [49]. However, when analysing the expression profiles of ChoK $\alpha$ and ethanolamine kinase, Ling et al. [50] observed that $\mathrm{ChoK} \alpha$ was expressed at lower levels in MCF7 cells compared with the HepG2 cancer cell line. In any case, we show that treatment of HepG2 and MCF7 cells with PL48 resulted in a $43 \%$ or $22 \%$ reduction in ChoK $\alpha$ protein levels, respectively (Figure 8). 

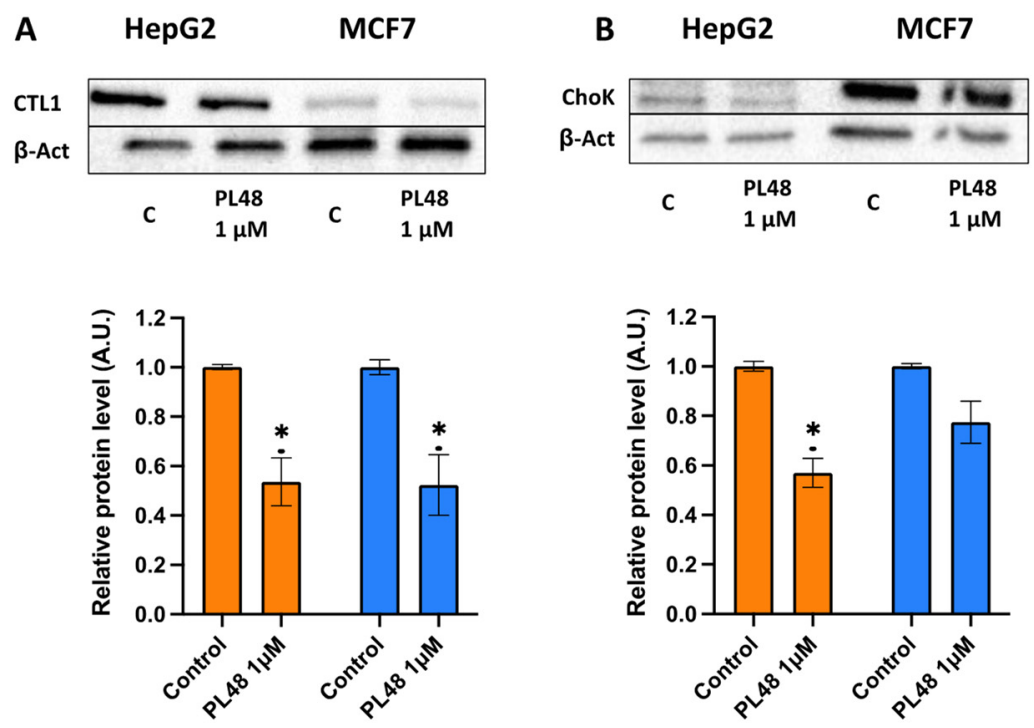

Figure 8. Effect of PL48 on CTL1 and ChoK protein levels in HepG2 and MCF7 cells. Cells were incubated without PL48 (control) or with $1 \mu \mathrm{M}$ PL48 for $48 \mathrm{~h}$. (A) Western blots show representative results of experiments repeated three times. (B) Protein levels in the samples were normalised to their respective $\beta$-actin levels and expressed as $x$-fold change compared with the corresponding control ratio (1.0). Data represent the mean \pm SEM of three independent experiments. ${ }^{*} p<0.05$.

Furthermore, as indicated in Figure 8, CTL1 was highly expressed in HepG2, and the levels of CTL1 were also significantly lower after HepG2 or MCF7 cells were exposed to PL48 for $48 \mathrm{~h}$. We can conclude that the use of ChoK $\alpha$ and CTL1 as therapeutic targets in these cancer cells is an appropriate approach to decrease cell proliferation due to the relationship between cell growth and choline metabolism.

\subsection{Effect of PL48 Treatment for $48 \mathrm{~h}$ on ChoK $\alpha$ and CTL1 Activities in MCF7 and HepG2 Cells}

In order to confirm the decrease in the expression and activity of the CTL1 transporter after treatment with PL48, we conducted a metabolic assay. Cells were incubated with the inhibitor for $48 \mathrm{~h}$, and after its withdrawal, were incubated for $10 \mathrm{~min}$ with [methyl${ }^{14} \mathrm{C}$ ]choline and choline uptake was determined. The results obtained show that in both types of cells, treatment with PL48 for $48 \mathrm{~h}$ inhibited the uptake of choline (Figure 9A). This inhibition is not produced by the direct action of the inhibitor on the transporter since PL48 was removed before the uptake assay; instead, inhibition of choline uptake appears to be the result of transporter activity after treatment with PL48 and can be considered an indirect measure of its expression. These data agree with the results obtained from the Western blot, which indicated a significant decrease in the expression levels of the CTL1 transporter. 

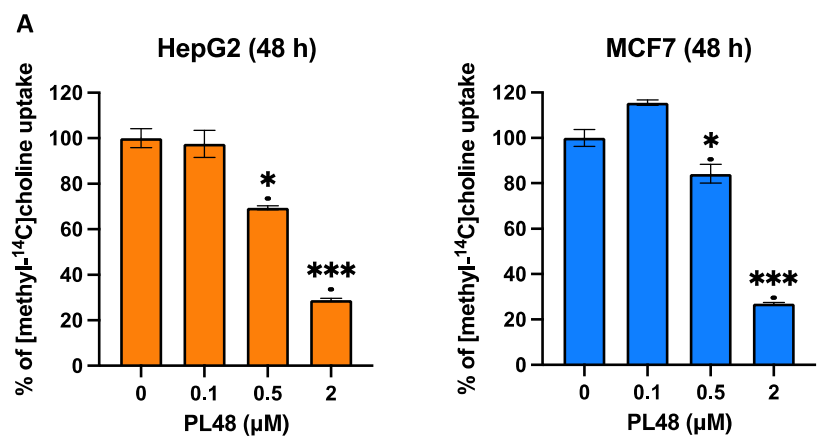

ChoK activity

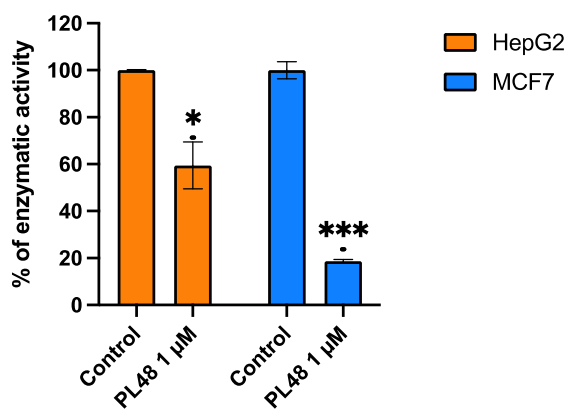

Figure 9. Effects of PL48 treatment on choline uptake (A) and on total cellular activity of ChoK (B) in HepG2 and MCF7 cancer cell lines. Cells were incubated with the inhibitor for $48 \mathrm{~h}$, and after its withdrawal, choline uptake and ChoK $\alpha$ activity were determined. Data represent the mean \pm SEM of two independent experiments conducted in triplicate. Results are normalised to their respective controls. ${ }^{*} p<0.05,{ }^{* * *} p<0.0001$.

Furthermore, experiments were performed to assess the total cellular activity of ChoK as previously described [29]. In brief, we obtained cell lysate containing the ChoK enzyme after treating cells with the inhibitor for $48 \mathrm{~h}$, observing a decrease in the activity of the enzyme in cells incubated with PL48 (Figure 9B). The results again confirm that PL48 results in the lower expression of ChoK.

\subsection{Effect of PL48 on Choline Metabolism in MCF7 and HepG2 Cells}

After establishing that PL48 caused the marked inhibition of recombinant human ChoK $\alpha$ activity and strongly inhibited $\left[{ }^{14} \mathrm{C}\right]$ choline uptake in MCF7 and HepG2 cells in vitro, we explored the effects of the long-term exposure of these cells to PL48 on choline metabolism. To this end, we exposed the cells to this compound for a $48 \mathrm{~h}$ period and analysed the distribution of total radiolabelled choline incorporated into the cell.

In these experiments, choline-labelled metabolites were extracted from the cells with a mixture of aqueous and organic solvents to determine the distribution of choline incorporated into the two phospholipids, PC and SM, and water-soluble metabolites. As can be seen in Table 1, HepG2 cells incorporated significantly higher levels of radioactivity than MCF7 cells, which is in accordance with the results of Western blot experiments, showing that choline uptake is more active in the hepatoma cell line. It is noteworthy that in this cell line, approximately $77 \%$ of the intracellular radioactivity was associated with the aqueous phase, whilst the lipid fraction accounted for only $23 \%$ of the total radioactivity incorporated into the cells. In MCF7 cells, $16 \%$ of the labelling was observed in the lipid-soluble fraction. 
Table 1. Effect of PL48 on [methyl- ${ }^{14} \mathrm{C}$ ]choline incorporation in HepG2 and MCF7. Cells were treated with $1 \mu \mathrm{M}$ PL48 for $48 \mathrm{~h}$. Then, they were incubated with [methyl- ${ }^{14} \mathrm{C}$ ]choline as described in the methods section. The total incorporation of choline and the incorporation of choline into ChoP and PC are expressed as nmol of choline incorporated per $\mathrm{mg}$ of cell protein and represent the mean \pm SEM of two independent experiments conducted in triplicate. ${ }^{*} p<0.05$.

\begin{tabular}{ccccccc}
\hline & Total & HepG2 & ChoP & PC & Total & MCF7 \\
& $32.11 \pm 2.09$ & $23.74 \pm 1.56$ & $7.15 \pm 0.61$ & $13.46 \pm 0.99$ & $9.64 \pm 0.62$ & $2.21 \pm 0.62$ \\
\hline Control & $32.15 \pm 1.33 *$ & $16.3 \pm 1.49 *$ & $3.37 \pm 0.30 *$ & $10.22 \pm 0.41 *$ & $6.70 \pm 0.63 *$ & $2.38 \pm 0.23$ \\
\hline
\end{tabular}

We also determined the radioactivity associated with both choline and PCho in the water-soluble phase. It is remarkable that in both cells, PCho was the main metabolite (85-95\% of total label) found in the aqueous phase, whilst choline did not account for more than $5-15 \%$ of this fraction, indicating a high rate of phosphorylation of $\left[{ }^{14} \mathrm{C}\right]$ choline incorporated by the cell (data not shown). In the organic phase of lipids containing choline, we observed that PC accounted for more than $98 \%$ of the total radioactivity in the organic phase in both cell lines (data not shown). These results agree with those obtained by other authors who also showed that only a minor fraction of radiolabelled choline incorporated by different cell types is present as phospholipids [51,52].

Our results show that choline metabolism responds differently in HepG2 and MCF7 after prolonged exposure to PL48 (Table 1). In particular, $48 \mathrm{~h}$ of PL48 treatment significantly reduced the total incorporation of $\left[{ }^{14} \mathrm{C}\right]$ choline into cells, but the effect was more marked in HepG2 (35\% reduction in total choline incorporated by the cell) in comparison with MCF7 cells ( $25 \%$ reduction). This reduction, besides the downregulation of CTL1 mentioned above, clearly suggests that the apparent choline uptake is significantly diminished in cells chronically treated with the inhibitor.

Due to the decrease in choline uptake, we observed that the radioactivity associated with PCho after chronic PL48 treatment in MCF7 cells was significantly reduced (up to 30\%) with respect to that observed in control cells. Similarly, according to the drastic reduction in choline transport produced by PL48 treatment, the radiolabel of PCho dropped by up to $31 \%$ compared with control HepG2 cells. In addition, it is remarkable that the exposure of HepG2 to PL48 led to a drastic reduction (up to 53\%) in PC formation, whilst the PC radiolabel was unchanged in MCF7 when compared with control cells. These results agree with the suggestion that in HepG2 cells, inhibition of both ChoK and choline uptake contributes to a drop in PC levels, whilst in MCF7 the decrease in choline uptake is not reflected in a reduction in PC formation, presumably because since ChoK is only slightly affected by chronic PL48 treatment.

\section{Conclusions}

The results reported herein clearly demonstrate that PL48, a rationally designed ChoK $\alpha 1$ inhibitor, inhibits the activity of human recombinant $C h o K \alpha 1$ as well as choline uptake after 10 min exposure in both HepG2 and MCF7 cells in vitro. The results describe the kinetics of choline uptake and identify the choline transporter CTL1 as the main carrier responsible for supplying choline for PC synthesis in these two types of cells. However, treatment with PL48 for $48 \mathrm{~h}$ exerts a differential effect on the two cell lines. In HepG2, we observed the inhibition of choline uptake and CTL1 expression as well as inhibition of the activity and expression of ChoK. Therefore, it is likely that both mechanisms, namely, targeting choline uptake and ChoK activity, are responsible for the inhibition of PC synthesis and, consequently, that the efficacy of this inhibitor on cell proliferation is closely correlated with its capability to block choline uptake and ChoK $\alpha$ activity. In MCF7 cells, the results lead us to conclude that the decrease in choline intake after treatment with PL48 for $48 \mathrm{~h}$ is mainly responsible for the antiproliferative activity produced by the inhibitor in these cells. These cells express ChoK, but the decrease in its activity and expression after treatment with PL48 for $48 \mathrm{~h}$ is less than that observed in HepG2. 
The results obtained in this work indicate that PL48 inhibits not only Chok $\alpha 1$ activity and expression but also the uptake of choline through the CTL1 transporter (Figure 10). Both ChoK $\alpha 1$ and CTL1 proteins are promising therapeutic targets to inhibit cell proliferation in MCF7 and HepG2 cell lines. Our data show that PL48 is a good candidate for further preclinical evaluation as a potential anticancer drug.

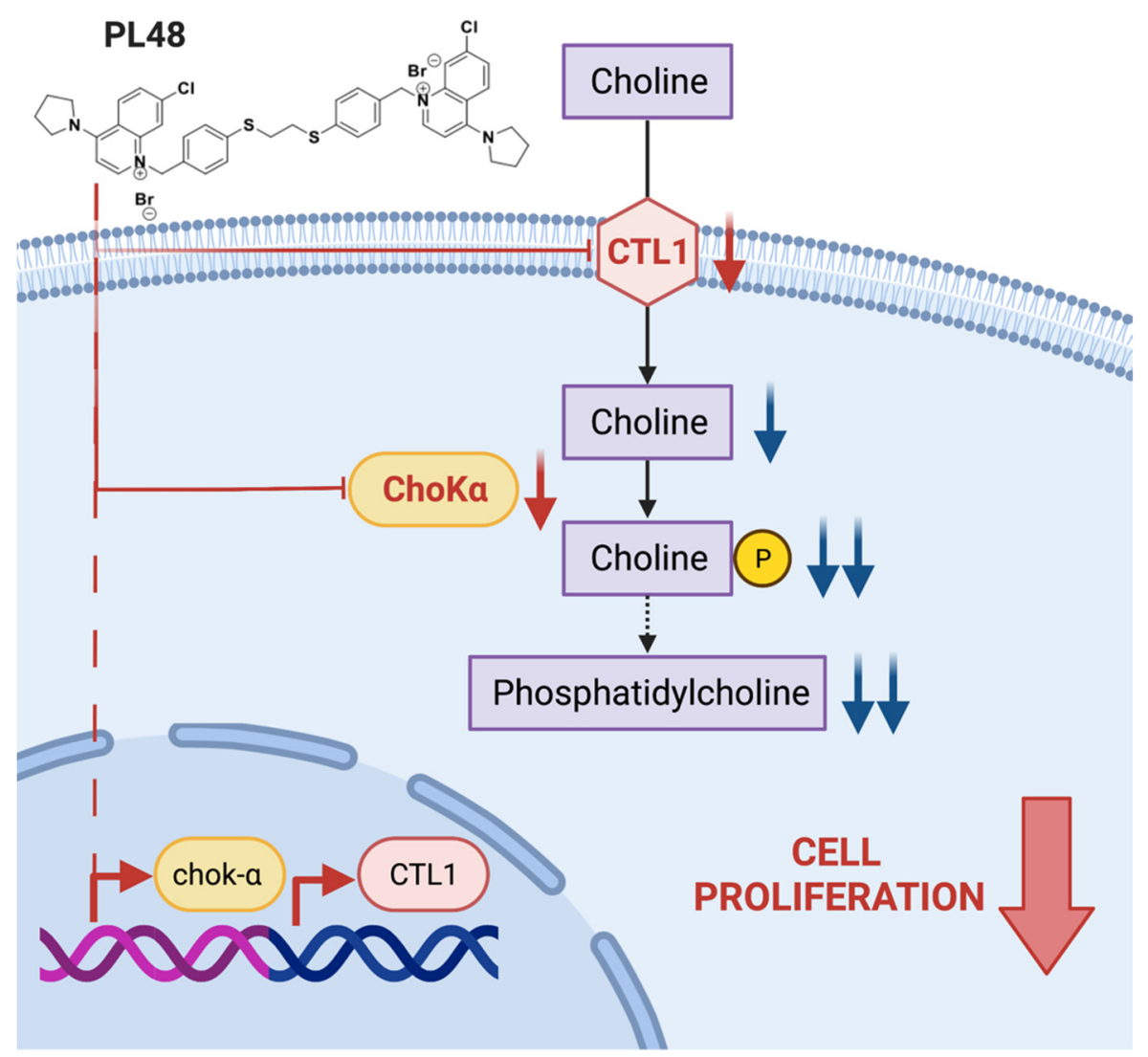

Figure 10. Scheme showing the action of PL48.

Author Contributions: P.G.-M. and A.S.-L. contributed equally to this work. Conceptualization, C.M., M.P.C.-J. and L.C.L.-C.; methodology, P.G.-M., A.S.-L., C.M., M.P.C.-J. and L.C.L.-C.; validation, P.G.-M., A.S.-L., C.M., M.P.C.-J. and L.C.L.-C.; formal analysis, P.G.-M., A.S.-L., A.L., C.M., M.P.C.-J. and L.C.L.-C.; investigation, P.G.-M., A.S.-L., A.L., M.P.C.-J., P.R.-M., P.M.L.-N., A.R., D.L., A.T., E.P. and L.C.L.-C., resources, M.P.C.-J. and L.C.L.-C.; writing-original draft preparation, P.G.-M., A.S.-L., C.M., M.P.C.-J. and L.C.L.-C.; writing-review and editing, P.G.-M., A.S.-L., C.M., M.P.C.-J. and L.C.L.-C.; resources, M.P.C.-J. and L.C.L.-C.; supervision, C.M., M.P.C.-J. and L.C.L.-C.; project administration, M.P.C.-J. and L.C.L.-C.; funding acquisition, M.P.C.-J. and L.C.L.-C. All authors have read and agreed to the published version of the manuscript.

Funding: This research work was supported by Ministerio de Ciencia e Innovación (PID2019109294RB-100) Project. This research was also aided by the Andalusian regional government (CTS236), B-CTS-216-UGR20 project and by the University of Perugia. Alberto Sola-Leyva holds a Formación de Doctores 2018 grant (ref. PRE2018-085440) from the Ministerio de Ciencia, Innovación y Universidades (Spain). Pilar M. Luque-Navarro holds a grant from Ministero dell'Istruzione (Italy). Emilio Parisini acknowledges the European Regional Development Fund (ERDF) project BioDrug (No. 1.1.1.5/19/A/004) and the Latvian Council of Science (grant No. lzp-2020/2-0013) for financial support.

Institutional Review Board Statement: Not applicable.

Informed Consent Statement: Not applicable.

Data Availability Statement: Not applicable. 
Conflicts of Interest: The authors declare no conflict of interest.

\section{References}

1. Sung, H.; Ferlay, J.; Siegel, R.L.; Laversanne, M.; Soerjomataram, I.; Jemal, A.; Bray, F. Global Cancer Statistics 2020: GLOBOCAN Estimates of Incidence and Mortality Worldwide for 36 Cancers in 185 Countries. CA A Cancer J. Clin. 2021, 71, 209-249. [CrossRef] [PubMed]

2. Falzone, L.; Salomone, S.; Libra, M. Evolution of Cancer Pharmacological Treatments at the Turn of the Third Millennium. Front. Pharmacol. 2018, 9, 1300. [CrossRef] [PubMed]

3. Fan, T.; Sun, G.; Sun, X.; Zhao, L.; Zhong, R.; Peng, Y. Tumor Energy Metabolism and Potential of 3-Bromopyruvate as an Inhibitor of Aerobic Glycolysis: Implications in Tumor Treatment. Cancers 2019, 11, 317. [CrossRef] [PubMed]

4. Huang, Y.; Sun, G.; Sun, X.; Li, F.; Zhao, L.; Zhong, R.; Peng, Y. The Potential of Lonidamine in Combination with Chemotherapy and Physical Therapy in Cancer Treatment. Cancers 2020, 12, 3332. [CrossRef]

5. Cheng, M.; Bhujwalla, Z.M.; Glunde, K. Targeting Phospholipid Metabolism in Cancer. Front. Oncol. 2016, 6, 266. [CrossRef]

6. Cheng, M.; Rizwan, A.; Jiang, L.; Bhujwalla, Z.M.; Glunde, K. Molecular Effects of Doxorubicin on Choline Metabolism in Breast Cancer. Neoplasia 2017, 19, 617-627. [CrossRef]

7. de Molina, A.R.; Gutiérrez, R.; Ramos, M.A.; Silva, J.M.; Silva, J.; Bonilla, F.; Sánchez, J.J.; Lacal, J.C. Increased Choline Kinase Activity in Human Breast Carcinomas: Clinical Evidence for a Potential Novel Antitumor Strategy. Oncogene 2002, 21, 4317-4322. [CrossRef]

8. Cecchetti, S.; Bortolomai, I.; Ferri, R.; Mercurio, L.; Canevari, S.; Podo, F.; Miotti, S.; Iorio, E. Inhibition of PhosphatidylcholineSpecific Phospholipase C Interferes with Proliferation and Survival of Tumor Initiating Cells in Squamous Cell Carcinoma. PLoS ONE 2015, 10, e0136120. [CrossRef]

9. Inazu, M. Choline Transporter-like Proteins CTLs/SLC44 Family as a Novel Molecular Target for Cancer Therapy. Biopharm. Drug Dispos. 2014, 35, 431-449. [CrossRef]

10. Inazu, M. Functional Expression of Choline Transporters in the Blood-Brain Barrier. Nutrients 2019, 11, 2265. [CrossRef]

11. Hong, B.S.; Allali-Hassani, A.; Tempel, W.; Finerty, P.J.; MacKenzie, F.; Dimov, S.; Vedadi, M.; Park, H.-W. Crystal Structures of Human Choline Kinase Isoforms in Complex with Hemicholinium-3. J. Biol. Chem. 2010, 285, 16330-16340. [CrossRef] [PubMed]

12. Arlauckas, S.P.; Popov, A.V.; Delikatny, E.J. Choline Kinase Alpha-Putting the ChoK-Hold on Tumor Metabolism. Prog. Lipid Res. 2016, 63, 28-40. [CrossRef] [PubMed]

13. Awwad, H.M.; Geisel, J.; Obeid, R. The Role of Choline in Prostate Cancer. Clin. Biochem. 2012, 45, 1548-1553. [CrossRef] [PubMed]

14. Ayub Khan, S.M.; Few, L.L.; See Too, W.C. Downregulation of Human Choline Kinase $\alpha$ Gene Expression by MiR-876-5p. Mol. Med. Rep. 2018, 17, 7442-7450. [CrossRef]

15. Mori, N.; Glunde, K.; Takagi, T.; Raman, V.; Bhujwalla, Z.M. Choline Kinase Down-Regulation Increases the Effect of 5-Fluorouracil in Breast Cancer Cells. Cancer Res. 2007, 67, 11284-11290. [CrossRef]

16. Yalcin, A.; Clem, B.; Makoni, S.; Clem, A.; Nelson, K.; Thornburg, J.; Siow, D.; Lane, A.N.; Brock, S.E.; Goswami, U.; et al. Selective Inhibition of Choline Kinase Simultaneously Attenuates MAPK and PI3K/AKT Signaling. Oncogene 2010, 29, 139-149. [CrossRef]

17. Clem, B.F.; Clem, A.L.; Yalcin, A.; Goswami, U.; Arumugam, S.; Telang, S.; Trent, J.O.; Chesney, J. A Novel Small Molecule Antagonist of Choline Kinase- $\alpha$ That Simultaneously Suppresses MAPK and PI3K/AKT Signaling. Oncogene 2011, 30, 3370-3380. [CrossRef]

18. Glunde, K.; Shah, T.; Winnard, P.T.; Raman, V.; Takagi, T.; Vesuna, F.; Artemov, D.; Bhujwalla, Z.M. Hypoxia Regulates Choline Kinase Expression through Hypoxia-Inducible Factor-1 $\alpha$ Signaling in a Human Prostate Cancer Model. Cancer Res. 2008, 68, 172-180. [CrossRef]

19. Rubio-Ruiz, B.; Figuerola-Conchas, A.; Ramos-Torrecillas, J.; Capitán-Cañadas, F.; Ríos-Marco, P.; Carrasco, M.P.; Gallo, M.Á.; Espinosa, A.; Marco, C.; Ruiz, C.; et al. Discovery of a New Binding Site on Human Choline Kinase A1: Design, Synthesis, Crystallographic Studies, and Biological Evaluation of Asymmetrical Bispyridinium Derivatives. J. Med. Chem. 2014, 57, 507-515. [CrossRef]

20. Sola-Leyva, A.; López-Cara, L.C.; Ríos-Marco, P.; Ríos, A.; Marco, C.; Carrasco-Jiménez, M.P. Choline Kinase Inhibitors EB-3D and EB-3P Interferes with Lipid Homeostasis in HepG2 Cells. Sci. Rep. 2019, 9, 5109. [CrossRef]

21. Sahún-Roncero, M.; Rubio-Ruíz, B.; Conejo-García, A.; Velázquez-Campoy, A.; Entrena, A.; Hurtado-Guerrero, R. Determination of Potential Scaffolds for Human Choline Kinase A1 by Chemical Deconvolution Studies. ChemBioChem 2013, 14, 1291-1295. [CrossRef]

22. Schiaffino-Ortega, S.; Baglioni, E.; Mariotto, E.; Bortolozzi, R.; Serrán-Aguilera, L.; Ríos-Marco, P.; Carrasco-Jimenez, M.P.; Gallo, M.A.; Hurtado-Guerrero, R.; Marco, C.; et al. Design, Synthesis, Crystallization and Biological Evaluation of New Symmetrical Biscationic Compounds as Selective Inhibitors of Human Choline Kinase A1 (ChoK $\alpha 1)$. Sci. Rep. 2016, 6, 23793. [CrossRef] [PubMed]

23. Serrán-Aguilera, L.; Mariotto, E.; Rubbini, G.; Castro Navas, F.F.; Marco, C.; Carrasco-Jiménez, M.P.; Ballarotto, M.; Macchiarulo, A.; Hurtado-Guerrero, R.; Viola, G.; et al. Synthesis, Biological Evaluation, in Silico Modeling and Crystallization of Novel Small Monocationic Molecules with Potent Antiproliferative Activity by Dual Mechanism. Eur. J. Med. Chem. 2020, $207,112797$. [CrossRef] [PubMed] 
24. Haga, T. Molecular Properties of the High-Affinity Choline Transporter CHT1. J. Biochem. 2014, 156, 181-194. [CrossRef] [PubMed]

25. Hedtke, V.; Bakovic, M. Choline Transport for Phospholipid Synthesis: An Emerging Role of Choline Transporter-like Protein 1. Exp. Biol. Med. 2019, 244, 655-662. [CrossRef] [PubMed]

26. Saiki, I.; Yara, M.; Yamanaka, T.; Uchino, H.; Inazu, M. Functional Expression of Choline Transporter-Like Protein 1 in LNCaP Prostate Cancer Cells: A Novel Molecular Target. Biomol. Ther. 2020, 28, 195-201. [CrossRef] [PubMed]

27. Watanabe, S.; Nishijima, N.; Hirai, K.; Shibata, K.; Hase, A.; Yamanaka, T.; Inazu, M. Anticancer Activity of Amb4269951, a Choline Transporter-Like Protein 1 Inhibitor, in Human Glioma Cells. Pharmaceuticals 2020, 13, 104. [CrossRef]

28. Jiménez-López, J.M.; Carrasco, M.P.; Segovia, J.L.; Marco, C. Hexadecylphosphocholine Inhibits Phosphatidylcholine Biosynthesis and the Proliferation of HepG2 Cells. Eur. J. Biochem. 2002, 269, 4649-4655. [CrossRef]

29. Schiaffino-Ortega, S.; López-Cara, L.C.; Ríos-Marco, P.; Carrasco-Jimenez, M.P.; Gallo, M.A.; Espinosa, A.; Marco, C.; Entrena, A. New Non-Symmetrical Choline Kinase Inhibitors. Bioorganic Med. Chem. 2013, 21, 7146-7154. [CrossRef]

30. Rubio-Ruíz, B.; Conejo-García, A.; Ríos-Marco, P.; Carrasco-Jiménez, M.P.; Segovia, J.; Marco, C.; Gallo, M.A.; Espinosa, A.; Entrena, A. Design, Synthesis, Theoretical Calculations and Biological Evaluation of New Non-Symmetrical Choline Kinase Inhibitors. Eur. J. Med. Chem. 2012, 50, 154-162. [CrossRef]

31. Bligh, E.G.; Dyer, W.J. A rapid method of total lipid extraction and purification. Can. J. Biochem. Physiol. 1959, 37, 911-917. [CrossRef] [PubMed]

32. Bradford, M.M. A Rapid and Sensitive Method for the Quantitation of Microgram Quantities of Protein Utilizing the Principle of Protein-Dye Binding. Anal. Biochem. 1976, 72, 248-254. [CrossRef]

33. Zeisel, S.H. Choline Phospholipids: Signal Transduction and Carcinogenesis 1. FASEB J. 1993, 7, 551-557. [CrossRef]

34. Glunde, K.; Bhujwalla, Z.M.; Ronen, S.M. Choline Metabolism in Malignant Transformation. Nat. Rev. Cancer 2011, 11, 835-848. [CrossRef] [PubMed]

35. Wang, T.; Li, J.; Chen, F.; Zhao, Y.; He, X.; Wan, D.; Gu, J. Choline Transporters in Human Lung Adenocarcinoma: Expression and Functional Implications. Acta Biochim. Biophys. Sin. 2007, 39, 668-674. [CrossRef] [PubMed]

36. Sinclair, C.J.; Chi, K.D.; Subramanian, V.; Ward, K.L.; Green, R.M. Functional Expression of a High Affinity Mammalian Hepatic Choline/Organic Cation Transporter. J. Lipid Res. 2000, 41, 1841-1848. [CrossRef]

37. Morse, D.L.; Carroll, D.; Day, S.; Gray, H.; Sadarangani, P.; Murthi, S.; Job, C.; Baggett, B.; Raghunand, N.; Gillies, R.J Characterization of Breast Cancers and Therapy Response by MRS and Quantitative Gene Expression Profiling in the Choline Pathway. NMR Biomed. 2009, 22, 114-127. [CrossRef]

38. Michel, V.; Yuan, Z.; Ramsubir, S.; Bakovic, M. Choline Transport for Phospholipid Synthesis. Exp. Biol. Med. 2006, 231, 490-504. [CrossRef]

39. Sanchez-Lopez, E.; Zhong, Z.; Stubelius, A.; Sweeney, S.R.; Booshehri, L.M.; Antonucci, L.; Liu-Bryan, R.; Lodi, A.; Terkeltaub, R.; Lacal, J.C.; et al. Choline Uptake and Metabolism Modulate Macrophage IL-1 $\beta$ and IL-18 Production. Cell Metab. 2019, 29, 1350-1362.e7. [CrossRef]

40. Schiaffino-Ortega, S.; Mariotto, E.; Luque-Navarro, P.M.; Kimatrai-Salvador, M.; Rios-Marco, P.; Hurtado-Guerrero, R.; Marco, C.; Carrasco-Jimenez, M.P.; Viola, G.; López-Cara, L.C. Anticancer and Structure Activity Relationship of Non-Symmetrical Choline Kinase Inhibitors. Pharmaceutics 2021, 13, 1360. [CrossRef]

41. Castro-Navas, F.F.; Schiaffino-Ortega, S.; Carrasco-Jimenez, M.P.; Ríos-Marco, P.; Marco, C.; Espinosa, A.; Gallo, M.A.; Mariotto, E.; Basso, G.; Viola, G.; et al. New More Polar Symmetrical Bipyridinic Compounds: New Strategy for the Inhibition of Choline Kinase A1. Future Med. Chem. 2015, 7, 417-436. [CrossRef]

42. Sánchez-Martín, R.; Campos, J.M.; Conejo-García, A.; Cruz-López, O.; Báñez-Coronel, M.; Rodríguez-González, A.; Gallo, M.A.; Lacal, J.C.; Espinosa, A. Symmetrical Bis-Quinolinium Compounds: New Human Choline Kinase Inhibitors with Antiproliferative Activity against the HT-29 Cell Line. J. Med. Chem. 2005, 48, 3354-3363. [CrossRef] [PubMed]

43. de Molina, A.R.R.; Sarmentero-Estrada, J.; Belda-Iniesta, C.; Tarón, M.; de Molina, V.R.; Cejas, P.; Skrzypski, M.; Gallego-Ortega, D.; de Castro, J.; Casado, E.; et al. Expression of Choline Kinase Alpha to Predict Outcome in Patients with Early-Stage Non-Small-Cell Lung Cancer: A Retrospective Study. Lancet Oncol. 2007, 8, 889-897. [CrossRef]

44. Gokhale, S.; Xie, P. ChoK-Full of Potential: Choline Kinase in B Cell and T Cell Malignancies. Pharmaceutics 2021, $13,911$. [CrossRef]

45. Glunde, K.; Serkova, N.J. Therapeutic Targets and Biomarkers Identified in Cancer Choline Phospholipid Metabolism. Pharmacogenomics 2006, 7, 1109-1123. [CrossRef]

46. Gallego-Ortega, D.; de Molina, A.R.; Ramos, M.A.; Valdes-Mora, F.; Barderas, M.G.; Sarmentero-Estrada, J.; Lacal, J.C. Differential Role of Human Choline Kinase $\alpha$ and $\beta$ Enzymes in Lipid Metabolism: Implications in Cancer Onset and Treatment. PLoS ONE 2009, 4, e7819. [CrossRef] [PubMed]

47. Butler, L.M.; Perone, Y.; Dehairs, J.; Lupien, L.E.; de Laat, V.; Talebi, A.; Loda, M.; Kinlaw, W.B.; Swinnen, J.V. Lipids and Cancer: Emerging Roles in Pathogenesis, Diagnosis and Therapeutic Intervention. Adv. Drug Deliv. Rev. 2020, 159, 245-293. [CrossRef]

48. Ward, C.S.; Eriksson, P.; Izquierdo-Garcia, J.L.; Brandes, A.H.; Ronen, S.M. HDAC Inhibition Induces Increased Choline Uptake and Elevated Phosphocholine Levels in MCF7 Breast Cancer Cells. PLoS ONE 2013, 8, e62610. [CrossRef]

49. See Too, W.C.; Wong, M.T.; Few, L.L.; Konrad, M. Highly Specific Antibodies for Co-Detection of Human Choline Kinase A1 and A2 Isoforms. PLoS ONE 2010, 5, e12999. [CrossRef] 
50. Ling, C.S.; Yin, K.B.; Cun, S.T.W.; Ling, F.L. Expression Profiling of Choline and Ethanolamine Kinases in MCF7, HCT116 and HepG2 Cells, and the Transcriptional Regulation by Epigenetic Modification. Mol. Med. Rep. 2015, 11, 611-618. [CrossRef]

51. Al-Saeedi, F.; Welch, A.E.; Smith, T.A.D. [Methyl-3H]Choline Incorporation into MCF7 Tumour Cells: Correlation with Proliferation. Eur. J. Nucl. Med. Mol. Imaging 2005, 32, 660-667. [CrossRef] [PubMed]

52. Kuang, Y.; Salem, N.; Corn, D.J.; Erokwu, B.; Tian, H.; Wang, F.; Lee, Z. Transport and Metabolism of Radiolabeled Choline in Hepatocellular Carcinoma. Mol. Pharm. 2010, 7, 2077-2092. [CrossRef] [PubMed] 